\title{
Preparation of low-cost ceramic membranes for microfiltration using sugarcane bagasse ash as a pore-forming agent
}

\section{(Preparação de membranas cerâmicas de baixo custo para microfiltração usando cinza de bagaço de cana de açúcar como agente porogênico)}

\author{
R. M. Andrade', N. G. Jaques ${ }^{2}$, J. Sousa ${ }^{3}$, R. P. S. Dutra', D. A. Macedo ${ }^{1}$, L. F. A. Campos ${ }^{1 *}$ \\ ${ }^{1}$ Universidade Federal da Paraíba, Programa de Pós-Graduação em Ciência e Engenharia de Materiais, \\ 58051-900, João Pessoa, PB, Brazil \\ ${ }^{2}$ Universidade Federal de Campina Grande, Programa de Pós-Graduação em Ciência e Engenharia de \\ Materiais, Campina Grande, PB, Brazil \\ ${ }^{3}$ Faculdade São Francisco da Paraíba, Departamento de Engenharia Civil, Cajazeiras, PB, Brazil
}

\begin{abstract}
Ceramic membranes are of great industrial interest in separation processes. They are characterized by high chemical and thermal stabilities and filtration capacity at high temperatures $\left(>500{ }^{\circ} \mathrm{C}\right)$ in a wide range of $\mathrm{pH}$ values. However, the major disadvantage of ceramic membranes is the high-cost of production involving synthetic raw materials, usually alumina and zirconia. In this work, low-cost ceramic membranes were prepared by solid-state reactive firing using a mixture of kaolinite clay and sugarcane bagasse ash. Particle size distribution, thermal, mineralogical, and chemical composition analyses were carried out to study the raw materials. Technological properties and water permeability were investigated in samples fired between 800 and $1000{ }^{\circ} \mathrm{C}$. The filtration efficiency was measured by comparative analyses between the raw water and the filtrate. The mean pore size ranging from 2.5 to $6.0 \mu \mathrm{m}$ makes the sugarcane bagasse ash derived ceramic membranes suitable for microfiltration processes.
\end{abstract}

Keywords: ceramic membrane, kaolinite clay, sugarcane bagasse ash, water filtration.

\section{Resumo}

\begin{abstract}
Membranas cerâmicas são de grande interesse industrial em processos de separação. Elas são caracterizadas por elevada estabilidade químicaltérmica e capacidade de filtração em temperaturas acima de $500{ }^{\circ} \mathrm{C}$ em uma larga faixa de valores de pH. Entretanto, a grande desvantagem das membranas cerâmicas é o elevado custo de produção envolvendo matérias-primas sintéticas, geralmente alumina e zircônia. Nesse contexto, membranas cerâmicas de baixo custo foram preparadas por sinterização reativa usando uma mistura de argila caulinítica e cinza de bagaço de cana de açúcar. Análises de distribuição de tamanho de partícula, térmica, mineralógica e de composição química foram realizadas para estudar as matérias-primas. As propriedades tecnológicas $e$ de permeabilidade à água foram determinadas em amostras queimadas entre 800 e $1000{ }^{\circ} \mathrm{C}$. A eficiência de filtração foi medida através de análises comparativas entre a água bruta e o filtrado. O tamanho médio dos poros entre 2,5 e 6,0 $\mu \mathrm{m}$ viabiliza o uso das membranas derivadas de cinza de bagaço de cana de açúcar em processos de microfiltração.

Palavras-chaves: membrana cerâmica, cinza de bagaço de cana de açúcar, filtração de água.
\end{abstract}

\section{INTRODUCTION}

The insecurity provided by conventional treatment systems associated to the evolution of anthropic actions on the natural sources of water, as well as the periodic identification of new contaminating agents, brought the need to review the concepts of conventional water treatment. Current physicochemical operations may be insufficient to remove pollutants from most water bodies in Brazil and around the world [1]. In this context, membrane separation processes have consolidated as an emerging technology to

*liszandra@hotmail.com

Dhttps://orcid.org/0000-0002-6235-6446 replace conventional water treatment. A membrane can be defined as a barrier that acts selectively separating two or more phases, restricting partially or totally the transport of components between them under the application of an external force [2]. The great technological progress in the processing of ceramic materials allows obtaining membranes with strict control in the size and distribution of pores, increasing their selectivity. Based on pore size, the main membrane separation processes are microfiltration (MF), ultrafiltration (UF), nanofiltration (NF), and reverse osmosis (RO). All these processes use hydraulic pressure as the driving force to separate water from contaminating solid particles [3]. Two operating systems can be used in membrane filtration: cross-flow and dead-end filtration. In a typical cross-flow system, the flow runs parallel to the 
surface of the membrane. The pressure difference between the ends of the membrane causes the permeation of part of the solution through its pores (perpendicular flow), generating a permeate flow. In dead-end systems, the solution is forced to pass directly through the pores of the membrane. Materials with particle size larger than the membrane pores are retained, accumulating on its surface. Part of the solution carrying particles of size smaller than the membrane pores passes through the membrane as a filtrate [1].

Ceramic membranes are of great interest in separation processes due to their high chemical and thermal stability. In addition, they allow filtration at elevated temperatures (above $500{ }^{\circ} \mathrm{C}$ ) and over a wide $\mathrm{pH}$ range (from 1 to 14 ). Another advantage of these membranes is the possibility of cleaning with aggressive chemicals substances, organic solvents or water vapor. However, the major disadvantage of ceramic membranes is the high-cost of production involving synthetic raw materials, usually alumina and zirconia. Several studies have used clays and natural pore forming agents as raw materials to obtain low-cost ceramic membranes. Neelakandan et al. [4] studied ultrafiltration membranes using feldspar, ball clay, quartz, and calcium carbonate from India. Khemakhem et al. [5] and Vasanth et al. [6] used natural raw materials (kaolin, quartz, calcite, and dolomite) from India and Tunisia to prepare low-cost ceramic membranes for microfiltration. Chaves et al. [7] prepared ceramic membranes for ultrafiltration with pore size in the range of 0.02 to $0.1 \mu \mathrm{m}$ using bentonite, kaolin, and quartz from Paraíba/Brazil. Koshimizu and Morelli [8] reported the use of sawdust, starch and graphite as pore forming agents to improve the shape, distribution and size of pores in ceramic membranes. Recently, Kouras et al. [9] reported the use of calcite as a pore forming agent during the preparation of macroporous ceramic supports. Following our own experience with the development of low-cost ceramic membranes [10], the present study is focused on evaluating the effects of the firing temperature on the properties of porous ceramics membranes prepared by solid-state reactive firing of a mixture of kaolinite clay and $30 \mathrm{wt} \%$ sugarcane bagasse ash.

\section{MATERIALS AND METHODS}

The raw materials used in this study were kaolinite clay and sugarcane bagasse ash (SBA), both from the State of Paraíba (Brazil). The raw materials were milled separately in a disc mill, dried at $110^{\circ} \mathrm{C}$ and classified in a 200 mesh sieve. After that, raw materials were characterized by thermal (Shimadzu, DTG-60H), particle size distribution (Cilas, 1090, liquid mode), chemical composition (Shimadzu, EDX-700), and mineralogical (Shimadzu, XRD-7000, using $\mathrm{CuK} \alpha$ radiation generated at $30 \mathrm{~mA}$ and $40 \mathrm{kV}$ ) analysis techniques. A ceramic formulation containing $30 \mathrm{wt} \%$ of sugarcane bagasse ash and kaolinite clay was humidified with water $(7 \mathrm{wt} \%)$ to facilitate binding. Disk-shaped (35 $\mathrm{mm}$ in diameter and $6.6 \mathrm{~mm}$ in thickness) membranes were obtained (13 $\mathrm{g}$ of powder) by uniaxial pressing at 20
$\mathrm{MPa}$. The pressed samples were dried at $110{ }^{\circ} \mathrm{C}$ for $24 \mathrm{~h}$ and fired at 800,900 and $1000{ }^{\circ} \mathrm{C}$ for $2 \mathrm{~h}$ using a heating rate of $5{ }^{\circ} \mathrm{C} / \mathrm{min}$. Water absorption, porosity, and apparent density were obtained by the Archimedes method. The microstructural characterization of fracture surfaces was performed by scanning electron microscopy (SEM, LEO, 1430).

The permeability test of fired membranes was carried out using a lab-made water permeability testing apparatus consisting of two water reservoirs, water pump, alternative water passage, membrane reactor, disk-shaped membrane, and a permeate collection channel. The permeability analysis was conducted at room temperature under a pressure of $200 \mathrm{kPa}$. The samples were previously immersed in water for $24 \mathrm{~h}$ to saturate the pores and avoid cracking due to the high pressure gradient at the beginning of the analysis. The first $100 \mathrm{~mL}$ of the permeate was discarded to ensure flow stabilization. Then, the time to acquire $100 \mathrm{~mL}$ of permeate was determined 3 times for each membrane. The permeability $\left(\mathrm{L}_{\mathrm{p}}\right)$ and the average pore size $(\mathrm{R})$ of the membranes were determined by Poiseuille's law, as reported in [6]:

$$
\mathrm{L}_{\mathrm{P}}=\frac{\mathrm{J}}{\Delta \mathrm{p}}=\frac{\varepsilon \cdot \mathrm{R}^{2}}{8 \cdot \mu \cdot \tau \cdot \Delta \mathrm{x}}
$$

where $L_{p}$ is the permeability of the membrane $\left[\mathrm{m}^{3} /\left(\mathrm{m}^{2} . \mathrm{s} . \mathrm{kPa}\right)\right], \mathbf{J}$ is the water flow through the membrane $\left(\mathrm{m}^{3} / \mathrm{m}^{2} . \mathrm{s}\right), \Delta \mathrm{p}$ is the transmembrane pressure $(\mathrm{kPa}), \varepsilon$ is the apparent porosity of the membrane (\%), $\mathrm{R}$ is the average pore size (m), $\mu$ is the dynamic viscosity of water (Pa.s), $\tau$ is the tortuosity factor (used 1 for cylindrical pore), and $\Delta \mathrm{x}$ is the thickness of the membrane (m). The membranes fired at $1000{ }^{\circ} \mathrm{C}$ were used in the filtration process of the raw water of the Gramame river in João Pessoa (Paraíba, Brazil). For this purpose, $20 \mathrm{~L}$ of raw water were collected according to the criteria established by the Ministry of Health of the Brazilian Government [11]. In order to evaluate the filtration efficiency, physicochemical parameters of color, turbidity, and $\mathrm{pH}$ were investigated before and after the filtration process. The guidelines of the standard methods for the examination of water and wastewater [12] were used for performing the physicochemical analyzes.

\section{RESULTS AND DISCUSSION}

The results of thermogravimetric analysis (TGA) and differential thermal analysis (DTA) of the starting materials are shown in Fig. 1. Two endothermic peaks at 100 and $500{ }^{\circ} \mathrm{C}$ and one exothermic peak at $880{ }^{\circ} \mathrm{C}$ were observed for the kaolinite clay (Fig. 1a). The first mass loss (about $3.2 \mathrm{wt} \%$ ) in the range $50-230{ }^{\circ} \mathrm{C}$ was due to the evaporation of adsorbed water and corresponded to the first DTA peak at $100{ }^{\circ} \mathrm{C}$. The second mass loss (about $2.2 \mathrm{wt} \%$ ) in the range $400-600{ }^{\circ} \mathrm{C}$ was due to the dehydroxylation of the kaolinite and the formation of metakaolinite, which correlated with the second DTA peak at $500{ }^{\circ} \mathrm{C}$. The mass loss remained 

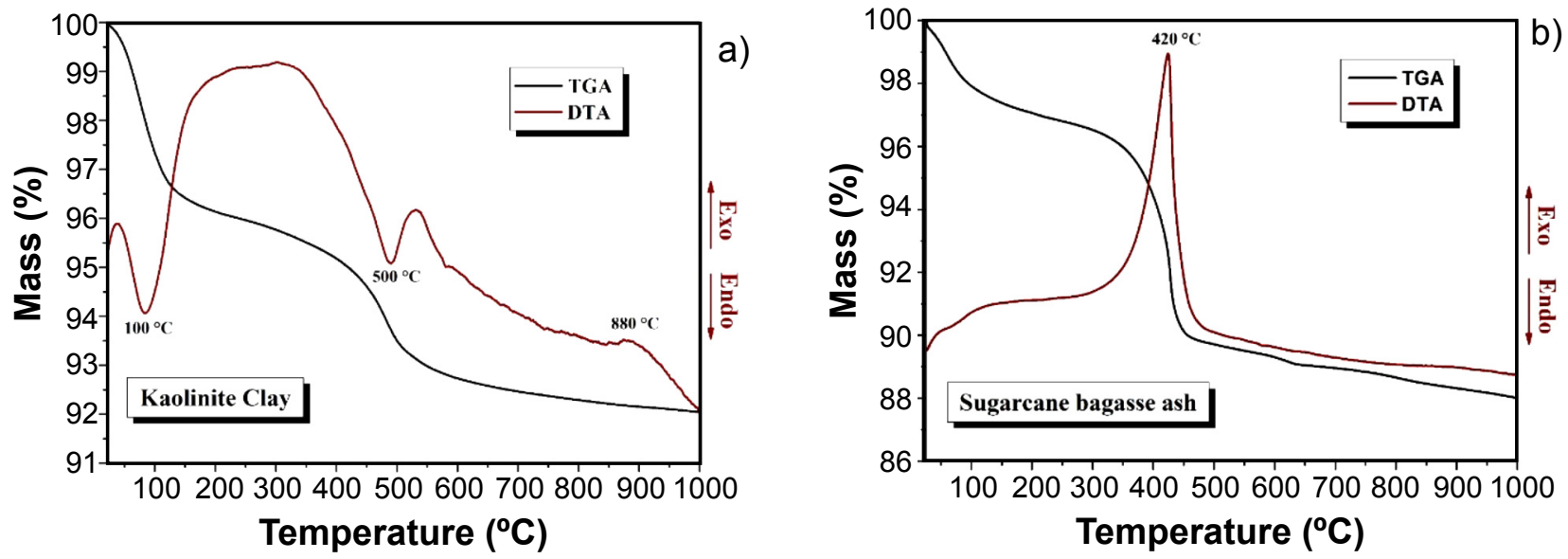

Figure 1: TGA and DTA curves of the raw materials: a) kaolinite clay; and b) sugarcane bagasse ash.

[Figura 1: Curvas de análises térmicas ATG e ATD das matérias-primas: a) argila caulinítica; e b) cinza de bagaço de cana.]

constant above $680^{\circ} \mathrm{C}$. The exothermic DTA peak at $880{ }^{\circ} \mathrm{C}$ corresponded to the formation of $\mathrm{Si}-\mathrm{Al}$ spinel, amorphous silica, and the onset of mullite (2:1) crystallization [13]. The mass loss (about $12 \mathrm{wt} \%$ ) assigned to the sugarcane bagasse ash (Fig. 1b) in the range $100-450{ }^{\circ} \mathrm{C}$ was due to the burning of organic matter and corresponded to the DTA exothermic peak at $420{ }^{\circ} \mathrm{C}$. The low mass loss temperature highlighted the sugarcane bagasse ash as a potential candidate to be used as a pore forming agent in the preparation of low-cost ceramic membranes [6].

The diffraction patterns of starting materials are shown in Fig. 2. Crystalline phases in the kaolinite clay (Fig. 2a) were indexed as kaolinite $\left[\mathrm{Al}_{2} \mathrm{Si}_{2} \mathrm{O}_{5}(\mathrm{OH})_{4}\right]$, mica muscovite $\left[\mathrm{KAl}_{2}\left(\mathrm{AlSi}_{3} \mathrm{O}_{10}\right)(\mathrm{OH})_{2}\right]$, calcium feldspar $\left[\mathrm{Ca}\left(\mathrm{Al}_{2} \mathrm{Si}_{2} \mathrm{O}_{8}\right)\right]$, and quartz $\left(\mathrm{SiO}_{2}\right)$. The sugarcane bagasse ash (Fig. 2b) consisted of quartz $\left(\mathrm{SiO}_{2}\right)$, calcium aluminum silicate $\left(\mathrm{Ca}_{3} \mathrm{Al}_{2} \mathrm{Si}_{3} \mathrm{O}_{12}\right)$ and potassium aluminum silicate $\left(\mathrm{KAlSi}_{3} \mathrm{O}_{8}\right)$. Kaolinite is a layered aluminosilicate $(1: 1)$ which exhibits a wide range of sintering temperature and quartz can increase the mechanical strength [14]. The chemical composition of the starting materials (expressed as a percentage of the oxides) is presented in Table I. The clay was essentially formed by silicon oxide $\left(\mathrm{SiO}_{2}\right)$, alumina $\left(\mathrm{Al}_{2} \mathrm{O}_{3}\right)$ and iron oxide $\left(\mathrm{Fe}_{2} \mathrm{O}_{3}\right)$, as expected for kaolinite-type clay and red ceramics. The high content of $\mathrm{SiO}_{2}(63.1 \mathrm{wt} \%)$ was due to the presence of kaolinite and quartz, as previously reported [15]. The predominance of $\mathrm{Si}, \mathrm{Al}, \mathrm{Ca}$, and $\mathrm{K}$ oxides in the sugarcane bagasse ash was in good accordance with the crystalline phases indexed by X-ray diffraction.

The particle size distribution curves of the raw materials and formulation with $30 \mathrm{wt} \%$ sugarcane bagasse ash are depicted in Fig. 3. For all samples, the particle size distribution presented a polymodal shape with mean size within $20-40 \mu \mathrm{m}$. With the addition of the sugarcane bagasse ash, higher mean particle size was obtained. These powders showed a wide particle size distribution $\left(D_{10}=2.61-13.60\right.$ $\mu \mathrm{m}, \mathrm{D}_{50}=14.67-38.10 \mu \mathrm{m}$ and $\left.\mathrm{D}_{90}=46.00-69.13 \mu \mathrm{m}\right)$. A wider distribution of powders is usually related to increasing the
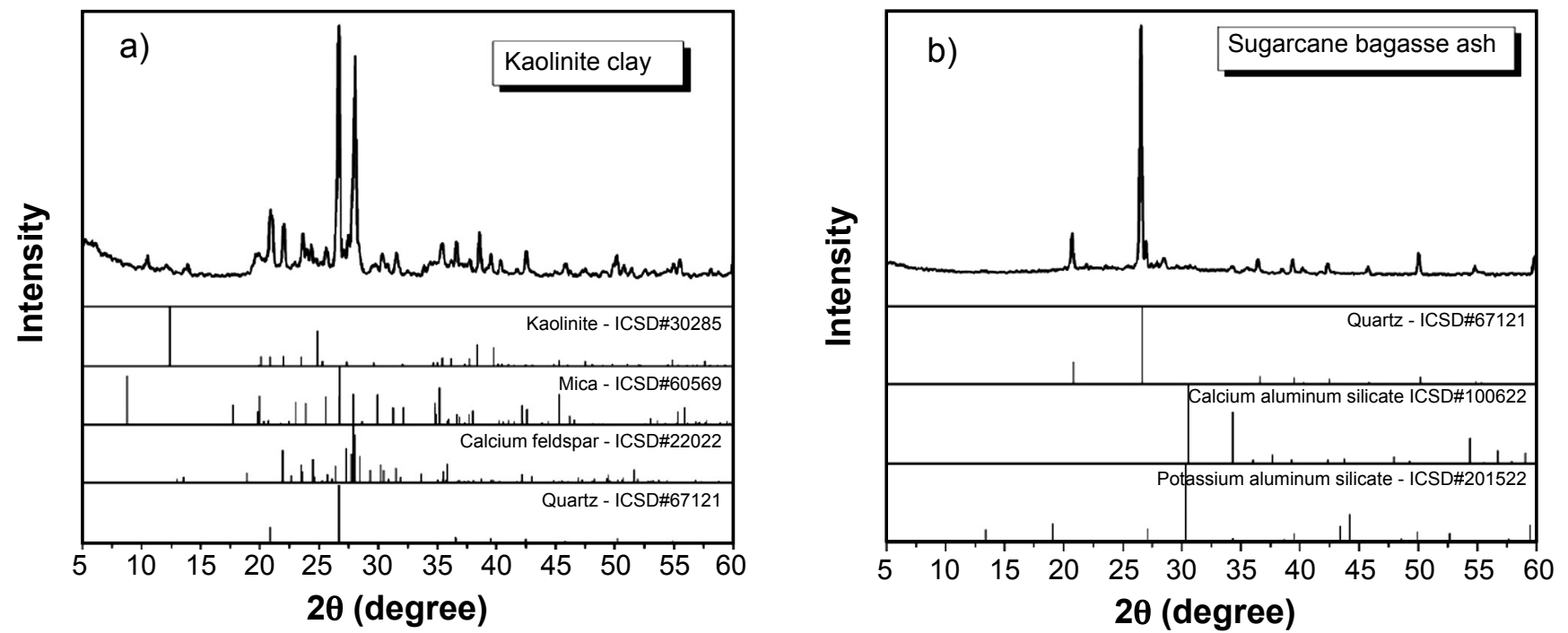

Figure 2: XRD patterns of: a) kaolinite clay; and b) sugarcane bagasse ash.

[Figura 2: Difratogramas de raios $X$ da: a) argila caulinítica; e b) cinza de bagaço de cana.] 
Table I - Chemical composition of the raw materials. [Tabela I - Composição química das matérias-primas.]

\begin{tabular}{ccc}
\hline Oxide $(\%)$ & $\begin{array}{c}\text { Kaolinite } \\
\text { clay }\end{array}$ & Sugarcane bagasse ash \\
\hline $\mathrm{SiO}_{2}$ & 63.10 & 57.46 \\
$\mathrm{Al}_{2} \mathrm{O}_{3}$ & 10.80 & 3.78 \\
$\mathrm{Fe}_{2} \mathrm{O}_{3}$ & 8.58 & 6.18 \\
$\mathrm{CaO}$ & 2.73 & 5.02 \\
$\mathrm{MgO}$ & 2.24 & 3.67 \\
$\mathrm{Na}_{2} \mathrm{O}$ & 1.97 & 0.19 \\
$\mathrm{~K}_{2} \mathrm{O}$ & 1.43 & 6.90 \\
$\mathrm{TiO}_{2}$ & 1.29 & 1.46 \\
$\mathrm{P}_{2} \mathrm{O}_{5}$ & - & 1.81 \\
Others & 0.66 & 1.53 \\
Loss on ignition (\%) & 7.2 & 12.0 \\
\hline
\end{tabular}
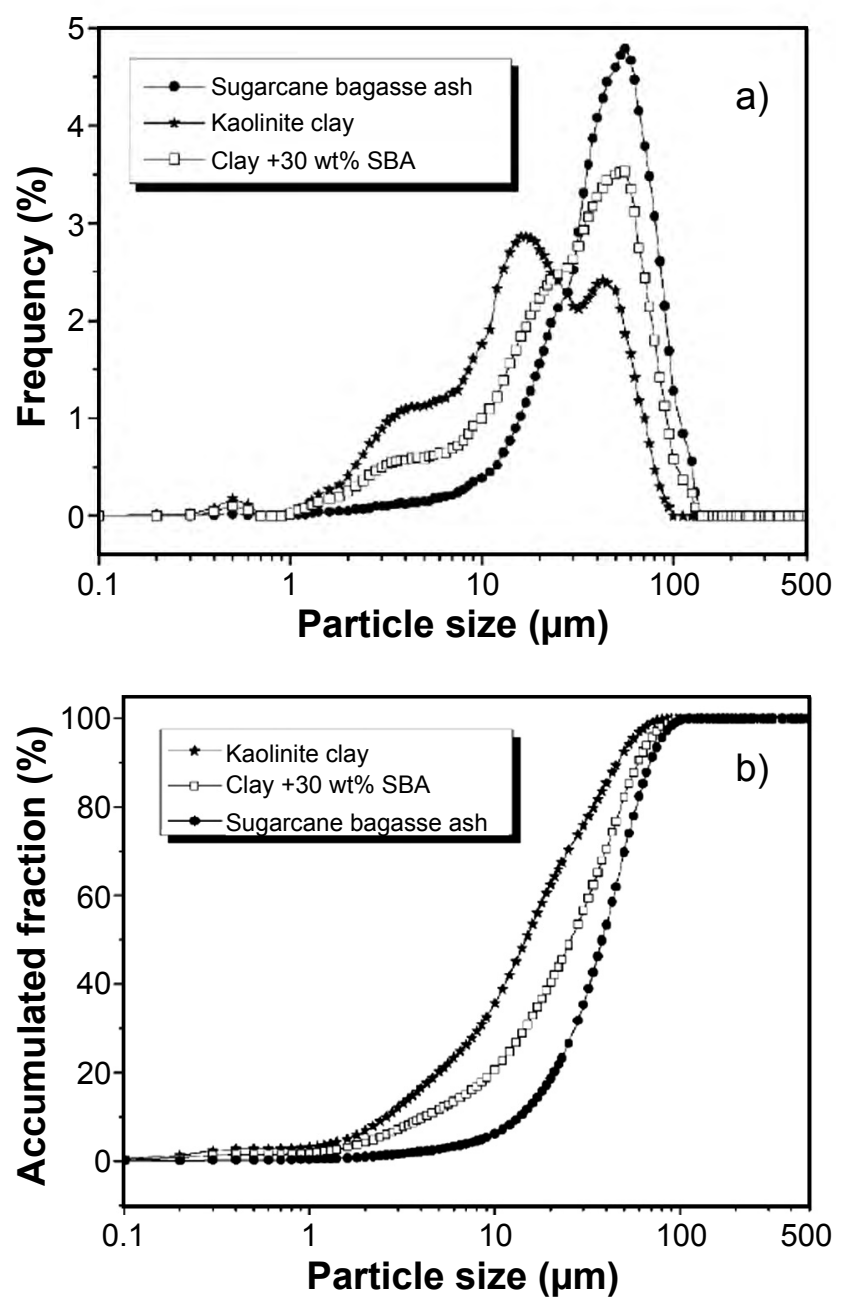

Figure 3: Particle size distribution curves of the raw materials and formulation: a) histogram; and b) accumulated volume.

[Figura 3: Curvas de distribuição de tamanho de partícula das matérias-primas: a) histograma; e b) volume acumulado.] packing density of particles. In this sense, smaller particles fit into the gaps of larger particles during the pressing process. This packing improvement is often responsible to increase densification of fired ceramics [16]. The concentrations were: i) particles smaller than $2 \mu \mathrm{m}: 6.88 \%$ (kaolinite clay), $4.18 \%$ (clay $+30 \mathrm{wt} \%$ sugarcane bagasse ash) and $0.92 \%$ (sugarcane bagasse ash - SBA); ii) particles between 2 and $20 \mu \mathrm{m}$ : 55.59\% (kaolinite clay), 36.15\% (clay $+30 \mathrm{wt} \%$ SBA) and $17.72 \%$ (SBA); and iii) particles larger than $20 \mu \mathrm{m}$ : $37.53 \%$ (kaolinite clay), 59.67\% (clay+30 wt\% SBA) and $81.36 \%$ (SBA). The particle size distribution was comprised in the range 1-100 $\mu \mathrm{m}$, regardless of the sample.

Apparent porosity and apparent density values as a function of the firing temperature are shown in Fig. 4. Porosities of $32.4 \%$ and $37.4 \%$ were obtained for samples fired at 800 and $900{ }^{\circ} \mathrm{C}$, respectively. This increase in porosity caused by increased firing temperature was associated with volatilization of the sugarcane bagasse ash at temperatures above that required to produce a liquid-phase (overfiring phenomenon), thus resulting in the appearance of pores, also reported in [17]. However, by increasing the temperature to $1000{ }^{\circ} \mathrm{C}$, it was observed that porosity decreased to $30.8 \%$ and apparent density increased. This behavior was due to the presence of flux agents such as mica, feldspar, and silicates in the raw materials (Fig. 2). The presence of flux agents activated a liquid-phase sintering process that filled up open pores by capillarity, improving the sample densification $[18,19]$. The average pore diameter increased continuously with the firing temperature (shown below) due to the liquidphase formed during the sintering process, which filled the pores of smaller diameter and consequently concentrated the larger ones. SEM images of fracture surfaces of membranes fired at 800,900 and $1000{ }^{\circ} \mathrm{C}$ are shown in Fig. 5. It was observed that the morphological characteristics of the membranes depended strongly on the firing temperature. Membranes fired at $1000{ }^{\circ} \mathrm{C}$ showed higher densification, in good agreement with the results of apparent porosity and density. In addition, the average pore size (darker regions)

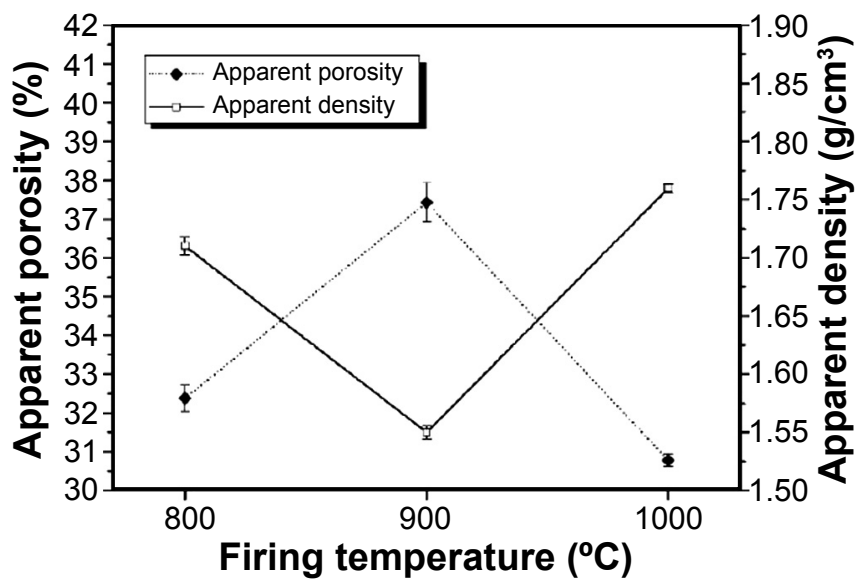

Figure 4: Apparent porosity and apparent density as a function of the firing temperature.

[Figura 4: Porosidade e densidade aparente em função da temperatura de queima.] 

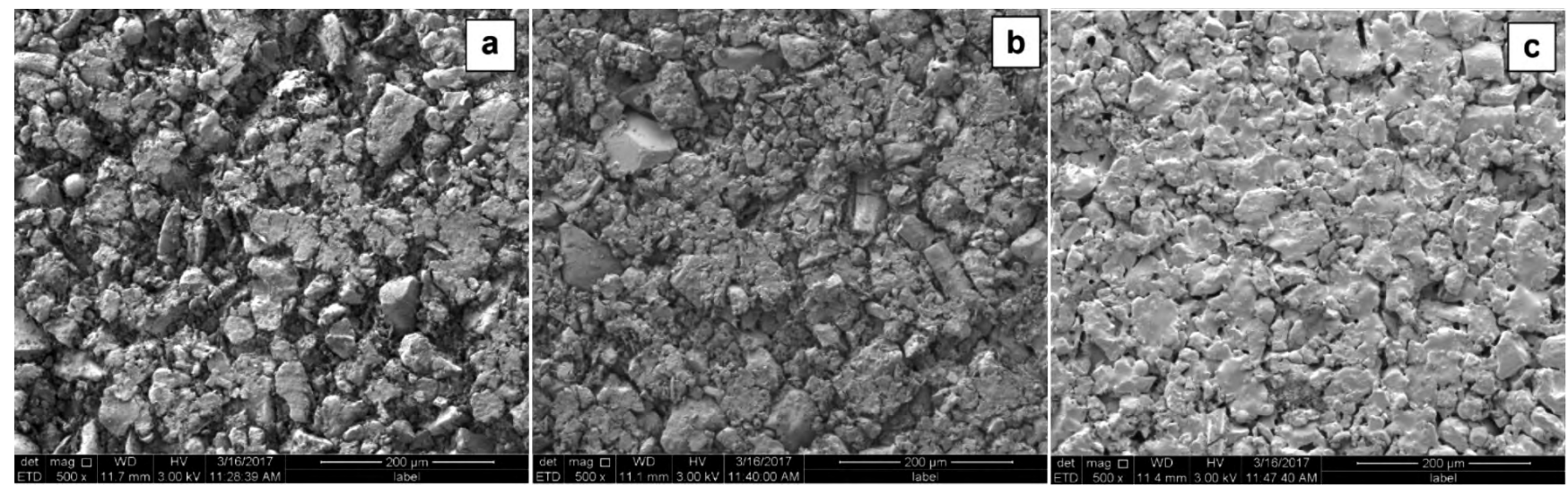

Figure 5: SEM micrographs of fracture surfaces of samples fired at: a) $800{ }^{\circ} \mathrm{C}$; b) $900{ }^{\circ} \mathrm{C}$; and c) $1000{ }^{\circ} \mathrm{C}$.

[Figura 5: Micrografias de MEV de superfícies de fratura de amostras queimadas a: a) $800{ }^{\circ} \mathrm{C}$; b) $900{ }^{\circ} \mathrm{C}$; e c) $1000{ }^{\circ} \mathrm{C}$.]

increased with increasing firing temperature, a phenomenon explained by the filling of the smaller pores.

Water permeability and average pore size of fired membranes, determined using Poiseuille's law, increased with increasing the firing temperature, as shown in Fig. 6. The mean pore size was found to be $2.5,4.5$ and $6.0 \mu \mathrm{m}$ to membranes made with kaolinite clay, clay $+30 \mathrm{wt} \%$ sugarcane bagasse ash, and sugarcane bagasse ash, respectively. Similar results were reported in [3], indicating the potential of the membranes obtained in this study for microfiltration

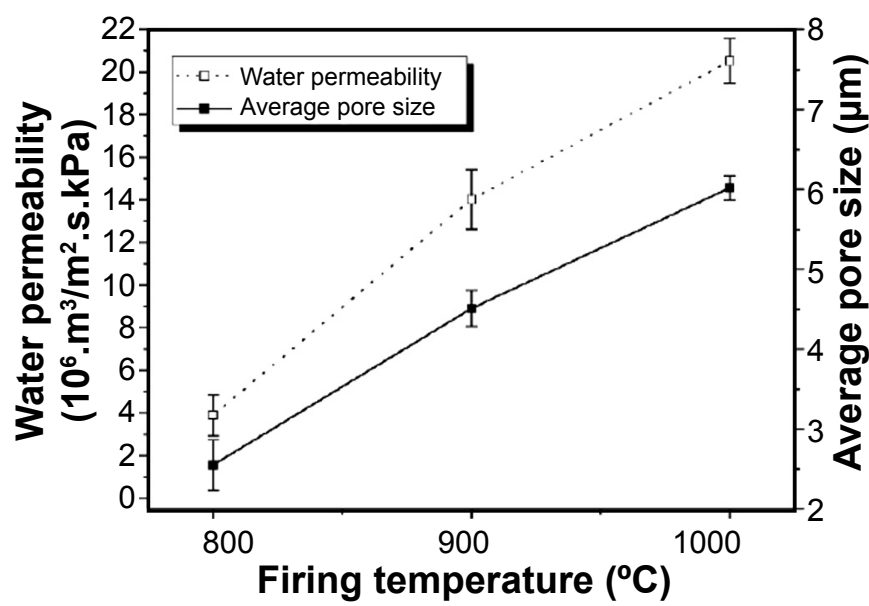

Figure 6: Water permeability and average pore size of membranes fired at different temperatures.

[Figura 6: Permeabilidade à água e tamanho médio dos poros de membranas em função da temperatura de queima.]

Table II - Characteristics of the water from Gramame river before and after filtration process.

[Tabela II - Características da água do rio Gramame antes e após o processo de filtração.]

\begin{tabular}{cccc}
\hline Sample & $\begin{array}{c}\text { Color } \\
\text { (u.c.) }\end{array}$ & $\begin{array}{c}\text { Turbidity } \\
\text { (NTU) }\end{array}$ & $\mathrm{pH}$ \\
\hline Raw water & 51.26 & 7.10 & 8.48 \\
Filtered water* & 44.47 & 5.36 & 6.97 \\
\hline
\end{tabular}

* - membrane fired at $1000{ }^{\circ} \mathrm{C}$. processes. The membranes fired at $1000{ }^{\circ} \mathrm{C}$ were applied in the treatment of raw water from the Gramame river in João Pessoa (State of Paraíba, Brazil). The filtration efficiency was evaluated by physical-chemical analyzes of color, turbidity and hydrogen potential $(\mathrm{pH})$. The characteristics of the raw effluent were used as a negative control and compared to the characteristics of the water after the filtration process. The characteristics of the raw and filtered effluent are shown in Table II. It was observed that these membranes favored a decrease of about 13\%, 25\% and $18 \%$ in color, turbidity, and $\mathrm{pH}$, respectively. These results suggested that sugarcane bagasse ash derived ceramic membranes can be used in microfiltration processes and water treatment.

\section{CONCLUSIONS}

Based on the results of this study, the following conclusions can be drawn: 1) sugarcane bagasse ash can be used as a pore-forming agent in the production of low-cost ceramic membranes; 2 ) the mean pore size ranging from 2.5 to $6.0 \mu \mathrm{m}$ makes the sugarcane bagasse ash derived ceramic membranes suitable for microfiltration processes; 3 ) the water permeability of the membranes was more sensitive to the variation of the average pore size than the relative amount of porosity; 4) the physical-chemical results confirmed the filtration efficiency of the obtained membranes, suggesting a possible application in water treatment systems.

\section{ACKNOWLEDGMENT}

Rivaildo M. Andrade thanks CAPES (Coordenação de Aperfeiçoamento de Nível Superior, Brazil) for the financial support during his master course.

\section{REFERENCES}

[1] R.P. Schneider, M.T. Tsutiya, Membranas filtrantes para o tratamento de água, esgoto e água de reuso, Ass. Bras. Eng. Sanit. Amb., S. Paulo (2001).

[2] R.D. Colle, C.A. Furtulan, S.R. Fontes. Ceram. Int. 37 (2011) 1161. 
[3] F.A. Silva, H.L. Lira, Cerâmica 52, 324 (2006) 276.

[4] C. Neelakandan, G. Pugazhenthi, A. Kuma, Eur. Polym. J. 39 (2003) 2383.

[5] S. Khemakhem, A. Larbot, R.B. Amar, Ceram. Int. 35 (2009) 55.

[6] D. Vasanth, G. Pugazhenthi, R. Uppaluri. J. Membr. Sci. 379 (2011) 154.

[7] A.C. Chaves, H.L. Lira, G.A. Neves, F.A. Silva, R.C.O. Lima, K.B. França, Cerâmica 59, 349 (2013) 192.

[8] L. Koshimizu1, M.R. Morelli, Cerâmica 58, 348 (2012) 516.

[9] N. Kouras, A. Harabi, F. Bouzerara, L. Foughali, A. Policicchi, S. Stelitano, F. Galiano, A. Figoli. J. Eur. Ceram. Soc. 37 (2017) 3159.

[10] R.M. Andrade, N.G. Jaques, J. Souza, R.P.S. Dutra, L.F.A. Campos, D.A. Macedo, BR1020170068730, Inst. Nac. Propr. Ind. (2017).

[11] D.B. Viana, F.B. Queiroz, M.H.B. Daniel, R.M.S.
Resende, S. Krüger Sabbag, Min. Saúde (2013).

[12] E.W. Rice, R.B. Baird, A.D. Eaton, L.S. Clesceri (Eds.), Stand. methods exam. water wastewater, $22^{\text {nd }}$ ed., Am. Pub. Health Ass., Washington (2012).

[13] Y.F. Chen, M.C. Wang, M.H. Hon, J. Eur. Ceram. Soc. 24 (2004) 2389.

[14] H.P.A. Alves, J.B. Silva, L.F.A. Campos, S.M. Torres, R.P.S. Dutra, D.A. Macedo, Ceram. Int. 42 (2016) 19086.

[15] S.G. Medeiros, R.P.S. Dutra, J.P.F. Grilo, A.E. Martinelli, C.A. Paskocimas, D.A. Macedo, Cerâmica 62, 363 (2016) 266.

[16] R.K. McGeary, J. Am. Ceram. Soc. 44 (1961) 513.

[17] V.S. Porto, M.F. Silva, T.B. Cruz, M.S.L. Cavalcanti, C.R. da Silva, Rev. Eletr. Mater. Proc. 7 (2012) 13.

[18] J.A. Baucia Jr, L. Koshimizu, C. Gibertoni, M.R. Morelli, Cerâmica 56, 339 (2010) 262.

[19] A. El-Kheshen, M. Zawrah, Ceram. Int. 29 (2003) 251. (Rec. 28/11/2018, Rev. 22/03/2019, Ac. 14/06/2019) 